\title{
Movement Patterns of American Eels in an Impounded Watercourse, as Indicated by Otolith Microchemistry
}

\author{
D. K. CAIRNS* \\ Department of Fisheries and Oceans, Box 1236, \\ Charlottetown, Prince Edward Island C1A 7M8, Canada \\ J. C. Shiao \\ Department of Zoology, College of Science, National Taiwan University, \\ Taipei, Taiwan 10617, Republic of China \\ Y. IIZUKA \\ Institute of Earth Sciences, Academia Sinica, Nankang, \\ Taipei, Taiwan, 11529, Republic of China \\ W.-N. TZENG \\ Department of Zoology, College of Science, National Taiwan University, \\ Taipei, Taiwan 10617, Republic of China

\section{D. MacPherson} \\ Department of Fisheries and Oceans, Box 1236, \\ Charlottetown, Prince Edward Island C1A 7M8, Canada
}

\begin{abstract}
Otolith Sr:Ca ratios were used to determine migrational histories of American eels Anguilla rostrata in an eastern Canadian coastal stream that is impounded at the head of tide. American eels sampled from the estuary were smaller $(41.0 \pm 9.3 \mathrm{~cm}[$ mean $\pm \mathrm{SD}], N=324)$ and younger (ages 1-4) than those in a freshwater pond $(65.0 \pm 7.5 \mathrm{~cm}, N=265$; ages 11-26) $2.5 \mathrm{~km}$ upstream of the head of tide. The $\mathrm{Sr}: \mathrm{Ca}$ ratios permitted identification of three migrational contingents. In 7 of $13(54 \%)$ American eels taken in the estuary, Sr:Ca ratios declined to 4.76 $\pm 1.22 \times 10^{-3}$, indicating direct migration from the sea to estuarine settlement sites. In the 6 other American eels (46\%), Sr:Ca ratios indicated an approach to freshwater soon after arrival in continental waters, followed by settlement in the estuary where ratios stabilized at $4.50 \pm 1.23$ $\times 10^{-3}$. In all 15 American eels sampled from the freshwater pond, Sr:Ca ratios indicated settlement in freshwater in the elver year and no subsequent change of habitat salinity (postelver ratio, 0.64 $\left.\pm 0.66 \times 10^{-3}\right)$. The lack of evidence for postelver movements between freshwater and brackish water contrasts with literature findings that such movements are common in systems where dams do not impede access to freshwater. Dams may hamper normal American eel movements between rivers and estuaries, even in watercourses in which some American eels are able to colonize freshwaters.
\end{abstract}

Recent declines of American eels Anguilla rostrata and European A. anguilla eel have focused attention on factors that limit numbers of these species. Possible causes of the declines include changes in ocean conditions, overfishing, pollution, and dams (Richkus and Whalen 2000). Busch et al. (1998) estimated that up to $84 \%$ of riverine habitat in U.S. eastern seaboard and Lake Ontario drainages lies upstream of dams. Although natural barriers would have impeded American eel access to some of this habitat, even if dams had not been

\footnotetext{
* Corresponding author: cairnsd@dfo-mpo.gc.ca
}

Received March 14, 2003; accepted July 2, 2003 built (Haro et al. 2000), it is clear that dams affect a substantial portion of potential eel habitat in North American fresh waters.

American eels are weak swimmers and are unable to leap over waterfalls or swim directly against strong currents. Eels ascending rivers attempt to circumvent obstacles by seeking lowcurrent routes, usually along banks that have a rough substrate, which permits the animal to advance with a serpentine motion (Tesch 1977). Eels smaller than about $11 \mathrm{~cm}$ can creep up vertical walls, but larger eels require a sloping substrate (Legault 1988). Thus some obstacles impose a size-dependent barrier to migration. Although eels are known to perform remarkable feats of migra- 
tion, such as surmounting waterfalls and invading landlocked lakes (Eales 1968), the general case appears to be that physical obstacles substantially constrain upstream movements (Porcher 1982; White and Knights 1997; Feunteun et al. 1998). However, factors enabling an eel to overcome obstacles in a river have not been quantitatively investigated. This means that the effects of dams and other structures on eel ascent of a river cannot be predicted from the nature of the obstacle.

Evaluations of the effects of dams on eel populations emphasize the classic catadromous paradigm that American eels ingress into freshwater, remain in freshwater during the yellow (growth) stage, and then return to the sea as silver eels (McCleave 2001). However, eels may exhibit other migratory patterns. Secor (1999) pointed out that diadromous fish commonly show intrapopulation variation in migration, some maintaining longterm residence in one habitat, others shifting among habitats. The development of microprobe analysis of $\mathrm{Sr}: \mathrm{Ca}$ ratios in fish otoliths permits determination of the migratory history of individual fish through salt, brackish, and freshwater because $\mathrm{Sr}: \mathrm{Ca}$ ratios are empirically linked to ambient salinity (Secor et al. 1995; Secor and Rooker 2000). Otolith Sr:Ca ratios decline sharply during the glass eel stage because of metabolic processes unrelated to ambient habitat (Tzeng et al. 1997). For subsequent stages, laboratory validation studies have confirmed that otolith $\mathrm{Sr}: \mathrm{Ca}$ ratios reflect ambient salinity, although temperature and diet also play a role (Tzeng 1996; Bath et al. 2000; Kraus and Secor 2003).

In many systems American eels exhibit seasonal migratory runs, especially in spring and fall (Smith and Saunders 1955; Medcof 1969; Jessop 1987). However, the occurrence of such runs does not necessarily mean that individual eels undertake regular seasonal movements. Application of the $\mathrm{Sr}$ :Ca method to American eels in an unimpounded stream in Nova Scotia showed that some individuals chose habitat of a certain salinity and then stayed there, whereas others showed irregular, often nonannual movements between the river and the estuary (Jessop et al. 2002). In the Hudson River estuary, $\mathrm{Sr}$ :Ca ratios of yellow American eels captured in brackish waters indicated that some animals had stayed in brackish water since their arrival as elvers, whereas others had spent varying periods in freshwater before returning to brackish water (Morrison et al. 2003). However, eels sampled in the freshwater upper reach of the estuary showed no evidence of residency in brack-

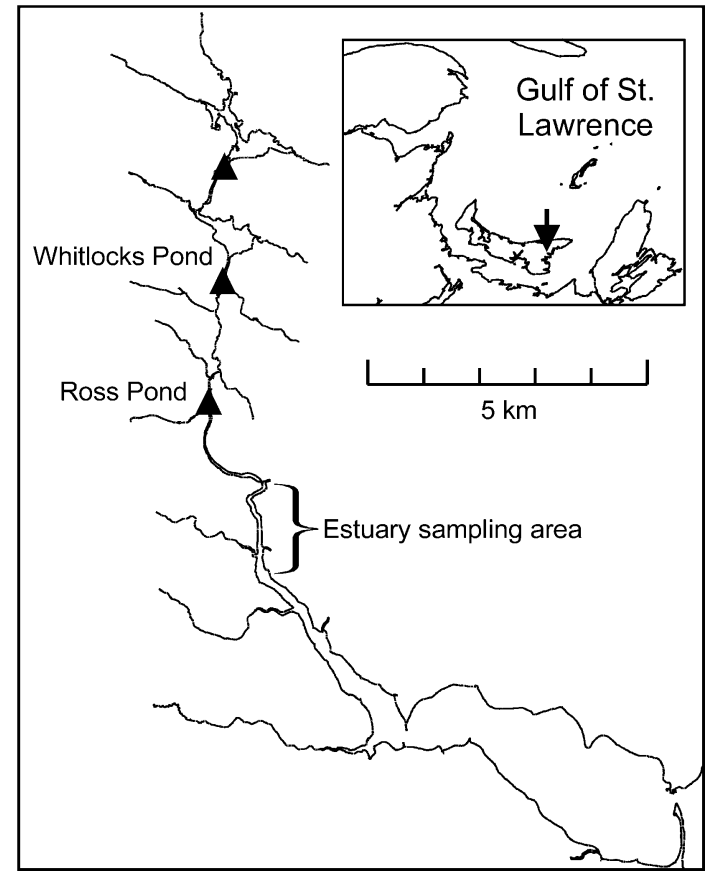

Figure 1.-Map of the Boughton River, Prince Edward Island, where movement patterns of American eels were examined with otolith microchemistry. Triangles indicate dams and the arrow indicates the study area.

ish water. Tzeng et al. (2003) found that the majority of Japanese eels Anguilla japonica sampled as silver eels in an estuary had shifted residence between freshwater and seawater, or vice versa, during their yellow eel phase. These studies suggest that movements between fresh and brackish waters are common in yellow-phase eels and that such movements are often irregular and nonannual.

Barriers to fish migration could potentially reduce American eel production in a watercourse (estuary and river) by hindering colonization of freshwater rearing areas or by suppressing movements, either annual or irregular, between river and estuary. This study uses otolith $\mathrm{Sr}$ :Ca ratios to determine patterns of river-estuary movements in American eels in a small system that is impounded at head of tide. These data are used to evaluate potential effects of dams on eel movements between habitats of varying salinity.

\section{Methods}

This study was conducted in the Boughton River, Prince Edward Island, Canada (Figure 1). The system is tidal from its mouth to the foot of Ross Dam, $12.5 \mathrm{~km}$ upstream. Water leaving Ross Pond flows through a rock channel that gradually de- 


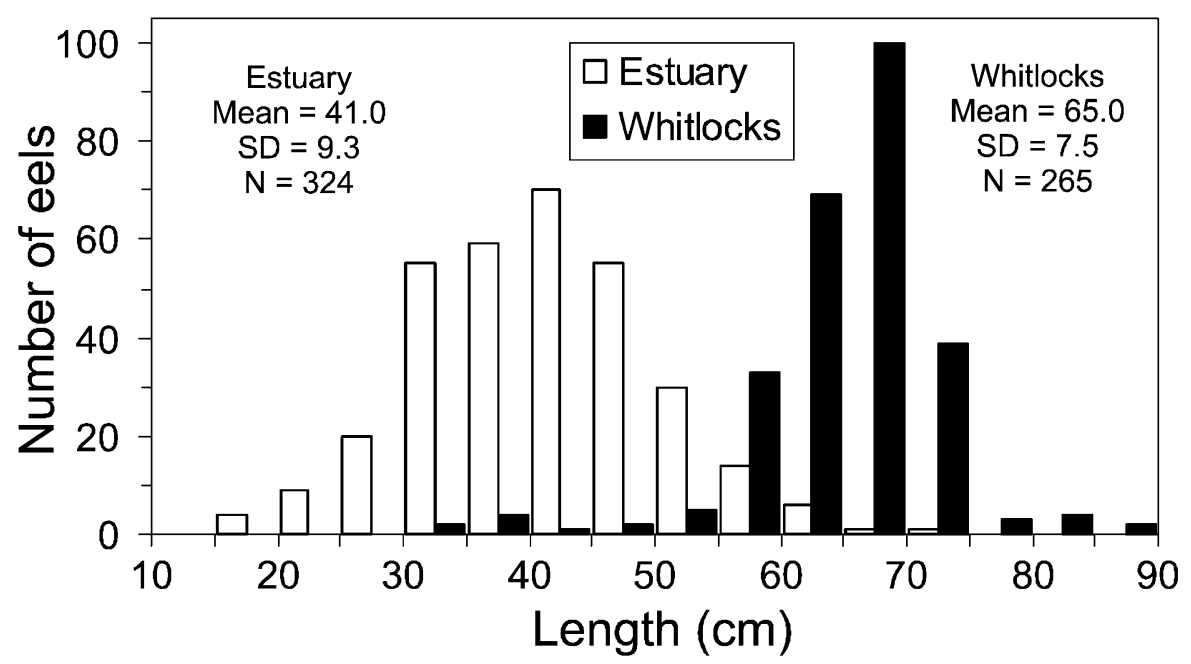

FIGURE 2.-Length-frequency distribution of American eels sampled in the Boughton River estuary and Whitlocks Pond.

scends to the natural stream bed. Whitlocks Pond, a 41-ha impoundment $2.5 \mathrm{~km}$ upstream from Ross Dam, has two outlets. On one there is concrete spillway with a vertical drop, and on the other the water flows through a rock channel that descends to the natural stream bed. Total stream length above Ross Dam is $8 \mathrm{~km}$. Both Ross and Whitlocks dams raise water 2-3 $\mathrm{m}$ above the outflowing stream level. Both structures are bordered by woodland and grassy habitat.

American eels were captured in the estuary and at Whitlocks Pond in May-August 1999 via fyke nets with stretch-mesh sizes of $24 \mathrm{~mm}$ in the leader and $19 \mathrm{~mm}$ in the funnel. All eels were measured live $(\mathrm{mm})$ in a V-shaped measuring trough. Eels not retained for otolith examination were released.

Otoliths from 28 American eels were embedded in Epofix resin and polished until the core was exposed on the surface. The polished otoliths were coated with a layer of carbon under a high-vacuum evaporator. The $\mathrm{Sr}$ and $\mathrm{Ca}$ concentrations from the primordium to the otolith edge were measured by an electron probe microanalyser (JXA-8900R) with a wavelength dispersive spectrometer. Quantitative analyses were conducted at an interval of approximately $10 \mu \mathrm{m}$, using beam conditions of 15 kiloelectron volts $(\mathrm{keV})$ for the acceleration voltage, $3 \mathrm{nA}$ for the current, and a beam size of $5 \times 4 \mu \mathrm{m}^{2}$. The wavelength dispersive spectrum was measured for $120 \mathrm{~s}$ at peak positions and 20 $\mathrm{s}$ at background positions for $\mathrm{Sr}$ and at $20 \mathrm{~s}$ and $10 \mathrm{~s}$, respectively, for $\mathrm{Ca}$. The beam power density of $2.3 \mathrm{~W} \cdot \mathrm{m}^{-2}$ was within the range of $0.5-3.0 \mathrm{~W}$
- $\mathrm{m}^{-2}$ suggested by Gunn et al. (1992), and the counting time was sufficient to ensure effective measurement. Calcite $\left(\mathrm{CaCO}_{3}, \mathrm{NMNH}\right.$ 136321) and strontiantite $\left(\mathrm{SrCO}_{3}, \mathrm{NMNH} \mathrm{R} 10065\right)$ were used as standards. The weight ratio of $\mathrm{Sr}: \mathrm{Ca}$ was calculated after correction with the ZAF method ( $\mathrm{Z}=$ atomic number effect, $\mathrm{A}=$ absorption of $\mathrm{X}$ rays within the specimen, $\mathrm{F}=$ fluorescence effects; Goldstein et al. 1984). After microprobe analysis, the otoliths were repolished and etched with 5\% ethelenediaminetetraacetic acid to enhance the annuli (Tzeng et al. 1994). Distances were measured from the core to the metamorphosis check (transition from leptocephalus larvae to glass eel), elver check (transition from glass eel to elver), and annuli, marking age in years.

Differences between group means were tested by $t$-test, and heterogeneity of regression slopes was tested by analysis of covariance (ANCOVA); significance was set at $\alpha=0.05$ in all tests.

\section{Results}

Salinities in the estuary sampling sites ranged from 3 to 15 ppt (surface) and 7 to 28 ppt (bottom), depending on tidal phase.

American eels captured in the estuary were on average much smaller than those taken in Whitlocks Pond (estuary $41.0 \pm 9.3 \mathrm{~cm}$ [mean $\pm \mathrm{SD}$ ], $N=$ 324; Whitlocks Pond $65.0 \pm 7.5 \mathrm{~cm}, N=265$; $t$ test, $P<0.0001$; Figure 2). In all measured otoliths, $\mathrm{Sr}$ :Ca ratios were about $10-14 \times 10^{-3}$ at the metamorphosis check (Figures 3-5). Subsequent patterns of $\mathrm{Sr}: \mathrm{Ca}$ ratio versus distance from the core 

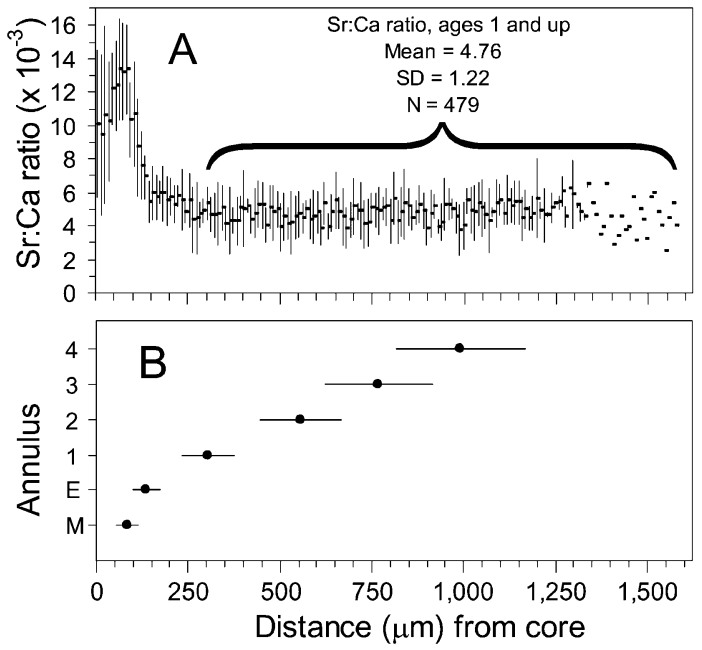

FIgURE 3.-For the seven American eels taken in the Boughton River estuary of Prince Edward Island that showed a saltwater-brackish water history, means and standard deviations are depicted for (A) the Sr:Ca ratios and (B) the distances of annuli from the otolith core; $N$ is the number of microprobe measurements, annulus $M$ is the metamorphosis check, annulus $E$ is the elver check, and subsequent annuli are annual checks.

fell into three groups. In seven eels taken in the estuary, Sr:Ca ratios declined steeply between the metamorphosis and elver checks, declined slowly between the elver check and the first annulus, and then stabilized without trend at a mean of $4.76 \pm$ $1.22 \times 10^{-3}$ (Figure 3). These eels are inferred to have a saltwater-brackish water (SB) individual life history. In six other eels from the estuary, $\mathrm{Sr}: \mathrm{Ca}$ ratios fell sharply between the elver check and the first annulus, and then descended to minimum values at ages $1-2$ before rebounding to stabilize at age 2 and older at a mean of $4.50 \pm 1.23 \times 10^{-3}$ (Figure 4). These eels are inferred to have a saltwater approach to freshwater-brackish water (SAB) life history. Minimum Sr:Ca ratios between the elver check and age 2 were significantly lower for $\mathrm{SAB}$ eels (mean $0.51 \pm 0.40 \times 10^{-3}$ ) than for SB eels (mean $1.82 \pm 0.65 \times 10^{-3}$; $t$-test, $P=0.001$ ). At sampling SB eels ranged from ages 1 to 4 ; all SAB eels were age 4 .

All 15 eels sampled from Whitlocks Pond showed a steep decline in $\mathrm{Sr}$ :Ca ratio between the metamorphosis and elver checks (Figure 5) and were categorized as saltwater to freshwater (SF) eels. Ratios at age 1 and older were stable at a mean of $0.64 \pm 0.66 \times 10^{-3}$. Ages at sampling for Whitlock eels ranged from 11 to 26 years.

Annulus distance from the core was linearly re-

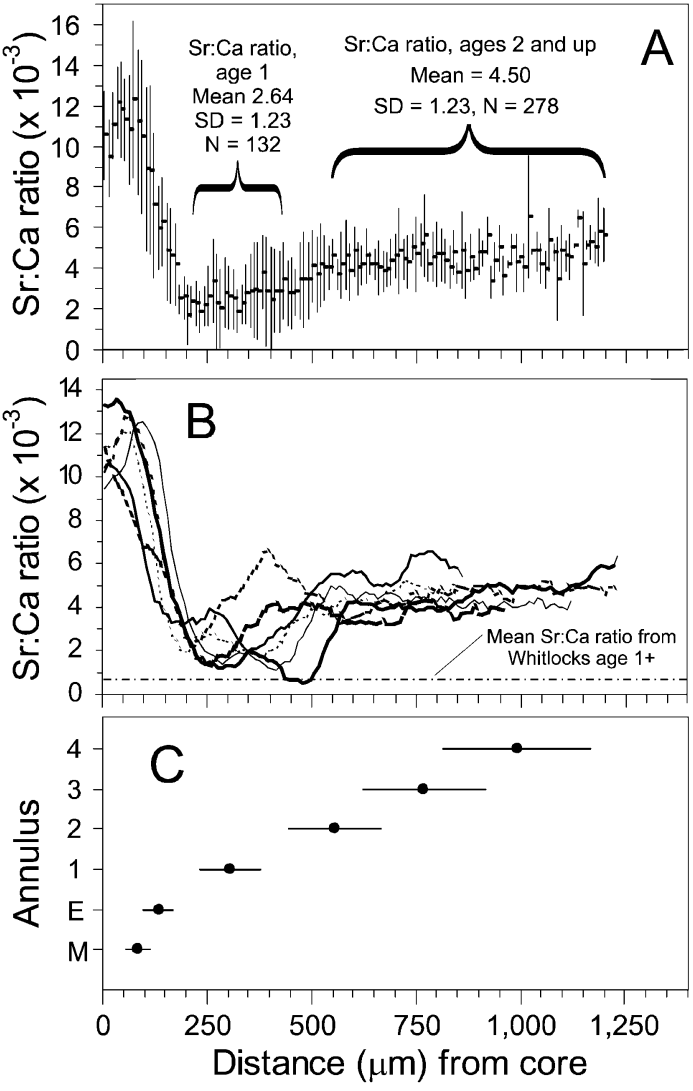

FIgURE 4.-For the six American eels taken in the Boughton River estuary of Prince Edward Island that showed a saltwater approach to freshwater-brackish water individual history, means and standard deviations are depicted for (A) the $\mathrm{Sr}$ :Ca ratios, (B) 9-point moving averages of the $\mathrm{Sr}: \mathrm{Ca}$ ratios of individual eels, and (C) the distances of annuli from the otolith core. Annulus $M$ is the metamorphosis check, annulus $E$ is the elver check, and subsequent annuli are annual checks.

lated to annulus number for the period from the elver check to the fourth annulus in all movement pattern groups (Figure 6). However, regression slopes differed significantly among groups (ANCOVA, $P<0.0001$ ), the SB group showing the fastest growth, followed by the SAB and SF groups.

\section{Discussion}

The Sr:Ca patterns revealed three distinct migratory contingents within the American eel population of an impounded coastal watercourse. About half $(54 \%)$ of the 13 eels captured in the estuary showed otolith $\mathrm{Sr}: \mathrm{Ca}$ ratios that steadily declined from the elver stage to a stable level, which is consistent with continued residency in 


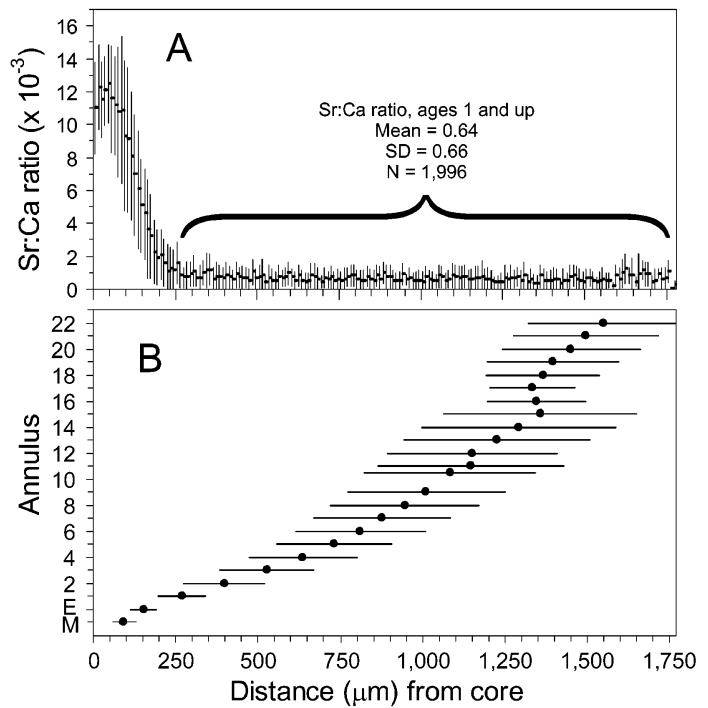

Figure 5.-For 15 American eels taken in Whitlocks Pond (Boughton River of Prince Edward Island) that showed a saltwater-freshwater individual history, means and standard deviations are depicted for (A) the $\mathrm{Sr}: \mathrm{Ca}$ ratios and (B) the distances of annuli from the otolith core. Annulus $M$ is the metamorphosis check, annulus $E$ is the elver check, and subsequent annuli are annual checks.

brackish waters. There was no dip in ratios between the elver stage and estuarine residency, which suggests that these eels did not attempt to ascend above the estuarine settlement area. For the other half of eels caught in the esturary $(46 \%), \mathrm{Sr}$ : $\mathrm{Ca}$ ratios dropped to $2.1 \times 10^{-3}$ or less after the elver stage before rising to a stable level. These eels apparently ascended to the upper estuary (or possibly side tributaries) within 2 years of arrival in continental waters, and subsequently fell back to establish residency in brackish waters. Both the timing and the duration of the approach to freshwater were highly variable among individuals (Figure 4B). The third group, those sampled in Whitlocks Pond, showed postelver $\mathrm{Sr}: \mathrm{Ca}$ ratios that descended quickly to stabilize at levels consistent with freshwater use. These eels apparently ascended directly to freshwater in their elver year, and remained there until they were captured.

In systems where eels can enter freshwater without encountering dams, $\mathrm{Sr}$ :Ca patterns indicate that many eels move between marine and freshwater or vice versa during the yellow eel stage (American eel: Jessop et al. 2002; Morrison et al. 2003; Japanese eel: Tzeng et al. 2002, 2003). Tzeng et al. (2002) also sampled eels above a dam; all showed exclusively freshwater $\mathrm{Sr}$ :Ca patterns in

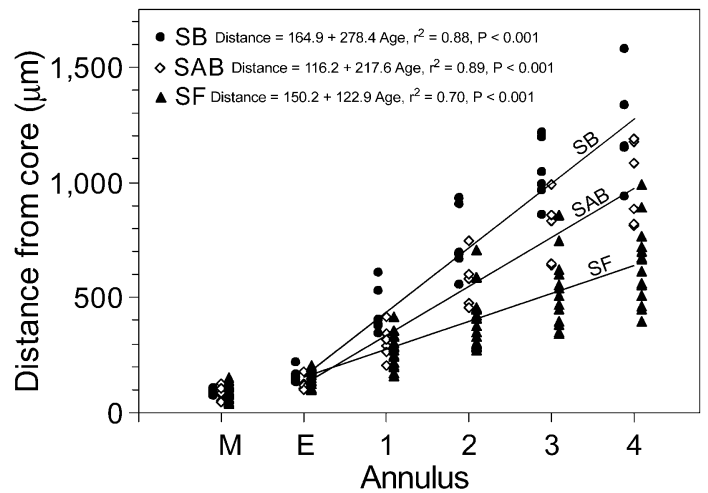

FIGURE 6.-Distances from the otolith core versus annulus counts for American eels (Boughton River of Prince Edward Island) showing saltwater-brackish water (SB), saltwater approach to freshwater-brackish water (SAB), and saltwater-freshwater (SF) movement patterns; $M$ is the metamorphosis check and $E$ is the elver check. Regression lines and equations are for the period from the elver check (age 0) to the 4th annulus (age 4).

the postelver period. American eels in the Boughton system showed no evidence of postelver movement between the estuary and freshwater. Some of the estuary-resident eels in the Boughton system approached freshwater but later returned to settle in the estuary. These eels may have attempted to enter freshwater, either for long-term residency or as part of an irregular excursion, but fell back because they were unable to surmount the dam at head of tide. Eels from Whitlocks Pond, all of which had entered freshwater during their elver year, may have been able to surmount the dam at the head of tide because their small size allowed them to scale vertical surfaces (Legault 1988), whereas the dam prevented passage of larger eels.

Our finding that Boughton River American eels show less movement between freshwater and brackish water than that reported for eels in unimpounded systems is consistent with literature reports that dams are a substantial impediment to eel movement, even in cases where some eels are able to surmount them (Smogor et al. 1995; White and Knights 1997; Feunteun et al. 1998).

Our data showed a nonoverlapping age distribution between American eels sampled in the Boughton estuary and Whitlocks Pond. The oldest eels in estuary samples were age 4 and the youngest eels from the pond were age 11 . The absence of eels younger than age 11 in the pond could be explained by a complete barrier to migration imposed 11 years before sampling. However, no change in the nature or severity of obstacles in the 
Boughton River is known for that time. Two other explanations for the divergence of ages between the two habitats are possible. Commercial fishing on Prince Edward Island is permitted in tidal waters only. Heavy exploitation of eels over the minimum size (46.0 cm up to 1997, $50.8 \mathrm{~cm}$ in 1998 and beyond) could have reduced the size and, therefore, the age distribution of eels in the estuary. The upper Boughton River contains an extensive network of creeks and marshes. Eels younger than age 11 may have been present in such habitats but absent from Whitlocks Pond.

Annuli in American eel otoliths from the Boughton estuary were more widely spaced than those from Whitlocks Pond, suggesting a more rapid growth rate in the estuary. In Nova Scotia, migrating silver eels with a dominant estuarine history grew more rapidly than those that had spent most of their time in freshwater (Jessop et al. 2002, unpublished data), but in Newfoundland eels grew faster in freshwater than in brackish coastal ponds (Gray and Andrews 1971). Migration contingents (Secor 1999) may show growth rates that vary among habitats. This does not necessarily mean that some habitats offer superior fitness to others because rapid growth in fishes is often accompanied by high mortality (Halpin 2000). The varying patterns of interhabitat eel movements may all have adaptive values that would be constrained by artificial barriers that prevent such movements.

Literature on the effects of dams on American eel populations emphasizes barriers to upstream colonization and turbine-induced mortality in downstream migrants (Richkus and Whalen 2000; McCleave 2001). Prince Edward Island has more than 800 dams (MacFarlane 1999) and most watercourses are impounded in one or several places. These dams do not prevent upstream colonization because eels are commonly found in impounded ponds (DKC., unpublished data); furthermore, turbine mortality does not occur because the dams are not used for water power. The findings of our study imply that dams in Prince Edward Island might negatively affect eel production by reducing the proportion of eels that are able to invade freshwater and by hindering normal migratory movements between freshwater and estuaries. However, dams could also benefit eel production by converting stream habitat, which is little used by eels on Prince Edward Island (Cairns 2002), to pond habitat, which has greater surface area and greater volume. Determination of the net effect of dams on eels requires further investigation.

\section{Acknowledgments}

We thank Kerry Oulton and Erin Breen for field and analytic assistance, Becky Peterson for information on the history of structures on the Boughton River, and Brian Jessop and Geoff Veinott for valuable comments on the manuscript.

\section{References}

Bath, G. E., S. R. Thorrold, C. M. Jones, S. E. Campana, J. W. McLaren, and J. W. H. Lam. 2000. Strontium and barium uptake in aragonitic otoliths of marine fish. Geochimica et Cosmochimica Acta 64:17051714.

Busch, W. D. N., S. J. Lary, C. M. Castilione, and R. P. McDonald. 1998. Distribution and availability of Atlantic coast freshwater habitats for American eel (Anguilla rostrata). U.S. Fish and Wildlife Service, Administrative Report Number 98-2, Amherst, New York.

Cairns, D. K. 2002. Substrate sedimentation and salmonid densities in Prince Edward Island streams. Pages 35-81 in D. K. Cairns, editor. Effects of land use practices on fish, shellfish, and their habitats on Prince Edward Island. Canadian Technical Report of Fisheries and Aquatic Sciences 2408.

Eales, J. G. 1968. The eel fisheries of eastern Canada. Fisheries Research Board of Canada Bulletin 166.

Feunteun, E., A. Acou, J. Guillouet, P. Laffaille, and A. Legault. 1998. Spatial distribution of an eel population (Anguilla anguilla L.) in a small coastal catchment of northern Brittany (France): consequences of hydraulic works. Bulletin Français de Pêche et de Pisciculture 349:129-139.

Goldstein, J. I., D. E. Newbury, P. Echlin, D. C. Joy, C. Fiori, and E. Lifshin. 1984. Scanning electron microscopy and X-ray micro-analysis: a text for biologists, materials scientists, and geologists. Plenum, New York.

Gray, R. W., and C. W. Andrews. 1971. Age and growth of the American eel (Anguilla rostrata (LeSueur)) in Newfoundland waters. Canadian Journal of Zoology 49:121-128.

Gunn, J. S., I. R. Harrowfield, C. H. Proctor, and R. E. Thresher. 1992. Electron microprobe analysis of fish otoliths: evaluation of techniques for studying age and stock discrimination. Journal of Experimental Marine Biology and Ecology 158:1-36.

Halpin, P. M. 2000. Habitat use by an intertidal saltmarsh fish: trade-offs between predation and growth. Marine Ecology Progress Series 198:203214 .

Haro, A., W. Richkus, K. Whalen, A. Hoar, W.-Dieter Busch, S. Lary, T. Brush, and D. Dixon. 2000. Population decline of the American eel: implications for research and management. Fisheries 25(9):7-16.

Jessop, B. M. 1987. Migrating American eels in Nova Scotia. Transactions of the American Fisheries Society 116:161-170.

Jessop, B. M., J.-C. Shiao, Y. Iizuka, and W.-N. Tzeng. 2002. Migratory behaviour and habitat use by American eels Anguilla rostrata as revealed by oto- 
lith microchemistry. Marine Ecology Progress Series 233:217-229.

Kraus, R. T., and D. H. Secor. 2003. Response of otolith Sr: $\mathrm{Ca}$ to a manipulated environment for young American eels. Pages 79-86 in D. A. Dixon, editor. Biology, management, and protection of catadromous eels. American Fisheries Society, Symposium 33, Bethesda, Maryland.

Legault, A. 1988. Le franchissement des barrages par l'escalade de l'anguille: étude en Sèvre Niortaise. [Overcoming dams by climbing in eels: a study in Sèvre Niortaise.] Bulletin Français de Pêche et de Pisciculture 308:1-10.

MacFarlane, R. E. 1999. An evaluation of the potential impacts of some Prince Edward Island impoundments on salmonid habitat. Master's thesis. Acadia University, Wolfville, Nova Scotia.

McCleave, J. D. 2001. Simulation of the impact of dams and fishing weirs on reproductive potential of silverphase American eels in the Kennebec River basin, Maine. North American Journal of Fisheries Management 21:592-605.

Medcof, J. C. 1969. Fishermen's reports of freshwater and saltwater migrations of Nova Scotia eels $(A n-$ guilla rostrata). Canadian Field-Naturalist 83:132138.

Morrison, W. E., D. H. Secor, and P. M. Piccoli. 2003. Estuarine habitat use by Hudson River American eels as determined by otolith strontium: calcium ratios. Pages 87-100 in D. A. Dixon, editor. Biology, management, and protection of catadromous eels. American Fisheries Society, Symposium 33, Bethesda, Maryland.

Porcher, J. 1982. Les passes à anguilles. [Fishways for eels.] Bulletin Français de Pêche et de Pisciculture 326/327:134-142.

Richkus, W. A., and K. Whalen. 2000. Evidence for a decline in the abundance of the American eel, $A n$ guilla rostrata (LeSueur), in North America since the early 1980s. Dana 12:83-97.

Secor, D. H. 1999. Specifying divergent migrations in the concept of stock: the contingent hypothesis. Fisheries Research 4:13-34.

Secor, D. H., A. Henderson-Arzapalo, and P. M. Piccoli. 1995. Can otolith microchemistry chart patterns of migration and habitat utilization in anadromous fishes? Journal of Experimental Marine Biology and Ecology 192:15-33.

Secor, D. H., and J. R. Rooker. 2000. Is otolith strontium a useful scalar of life cycles in estuarine fishes? Fisheries Research 46:359-371.

Smith, M. W., and J. W. Saunders. 1955. The American eel in certain fresh waters of the Maritime Provinces of Canada. Journal of the Fisheries Research Board of Canada 12:238-269.

Smogor, R. A., P. L. Angermeier, and C. K. Gaylord. 1995. Distribution and abundance of American eels in Virginia streams: tests of null models across spatial scales. Transactions of the American Fisheries Society 124:789-803.

Tesch, F.-W. 1977. The eel: biology and management of anguillid eels. Chapman and Hall, London.

Tzeng, W.-N. 1996. Effects of salinity and ontogenetic movements on strontium: calcium ratios in the otoliths of the Japanese eel, Anguilla japonica Temminck and Schlegel. Journal of Experimental Marine Biology and Ecology 199:111-122.

Tzeng, W.-N., K. P. Severin, and H. Wickström. 1997. Use of otolith microchemistry to investigate the environmental history of European eel Anguilla anguilla. Marine Ecology Progress Series 149:73-81.

Tzeng, W.-N., J. C. Shiao, and Y. Iizuka. 2002. Use of otolith $\mathrm{Sr}$ :Ca ratios to study the riverine migratory behaviors of Japanese eel Anguilla japonica. Marine Ecology Progress Series 245:213-221.

Tzeng, W.-N., J.-C. Shiao, Y. Yamada, and H. P. Oka. 2003. Life history patterns of Japanese eel Anguilla japonica in Mikawa Bay, Japan. Pages 285-294 in D. A. Dixon, editor. Biology, management, and protection of catadromous eels. American Fisheries Society, Symposium 33, Bethesda, Maryland.

Tzeng, W.-N., H. F. Wu, and H. Wickström. 1994. Scanning electron microscope analysis of annulus microstructure in otoliths of European eel, Anguilla anguilla. Journal of Fish Biology 45:479-492.

White, E. M., and B. Knights. 1997. Dynamics of upstream migration of the European eel, Anguilla anguilla (L.), in the Rivers Severn and Avon, England, with special reference to the effects of man-made barriers. Fisheries Management and Ecology 4:311324 . 